\title{
28. Geological Age of the Yosida-mura Shell-beds, Kagosima-ken, Kyusyu. III.
}

By Hisakatsu YABE, M. I. A.

(Comm. May 13, 1946.)

III, Continued.

Young Cenozoic deposits of Akasi coast are divisible into three parts intervened by two unconformities, as stated by $T$. Shikama, (1) namely:

Upper Harima beds, mostly of gravels and sands

Lower Harima beds, of sands, muds and gravels

Akasi beds, mostly of mud, with subordinate sandy parts

The Akasi beds correspond to the Stegodon beds of T. Makiyama and the lower part of the Upper Harima exposed at Nisiyagi in muddy facies is the Elephas beds, where remains of Elephas namadicus naumanni Makiyama were found in the conglomerate at the base. The unconformity beneath the almost horizontal Upper Harima is much more marked than that beneath the Lower Harima, the deposits, which according to him, fill up the shallow depressions formed by downwarping of the underlying Akasi beds. The Lower Harima contains marine molluscan shells at several horizons. The Maiko shell-beds once referred to above, with Chlamys yagurai and other shells, and lying directly under the Upper Harima gravels, is thought by him to be equivalent to the Lower Harima, at least in part. Stratigraphically the Lower Harima appearing much more intimately related to the Akasi than to the Upper Harima, the writer is tempted to separate the Lower Harima from the Upper and to unite it to the underlying Akasi, as follows:

H. Yabe

Harim beds

Upper Akasi beds

Lower Akasi beds
T. Shikama

Upper Harima beds

Lower Harima beds

Akasi beds

T. Makiyama ${ }^{2)}$ pointed out that some of the specimens from Akasi coast referred by T. Shikama to Parastegodon akashiensis do not belong to that species, being on the contrary identical with Parastegodon sugiyamai Tokunaga

1) T. Shikama : On Akasi Group (in Japanese). Jour. Geol. Soc. Japan, Vol. XLIII, No. 515, 1936.

2) J. Makiyama : Japonic Proboscidea. Mem. Coll. Sci., Kyoto Imp. Univ., Ser. B, Vol. XIV, No. 1, 1938, pp. 27-32. 
from Sikoku-Stegodon insignis sugiyamai (Tokunaga) of Makiyama, and they are derived from a horizon a little lower than that of Parastegodon akashiensis. $P$. sugiyamai as well as $P$. ? kwantoensis Tokunaga, the latter from the upper part of the Kakiu beds of Manpukuzi, Kakiu-mura, Tutuki-gun, province of Sagami (Kanagawa prefecture), of the Kwanto region, has been absorbed by F. Takai3) into Parastegodon aurorae (Matsumoto), which he took as a characteristic earliest Pleistocene (Sicilian) form; whereas, T. Makiyama) mentioned both $P$, aurorae and $P$. ? kwantoensis (his $P$. cf aurorae) as the Upper Pliocene species.

The Lower Akasi- or Stegodon beds is late Pliocene according to T. Shikama and the earliest Pleistocene according to F. Takai, whereas T. Makiyama entertains the belief probably to have here a case similar to the Siwalik Tatrot, which G. E. Pilgrim placed in the later Pliocene, W. D. Matthew, de ${ }^{5)}$ Terra and E. Lewis ${ }^{6}$ in the early Pleistocene, and E. H. Colbert ${ }^{7)}$ in the latest Pliocene. Archidiskodon planifrons (Falconer and Cautley) is a characteristic proboscidea of the Pinjor and Tatrot according to Lewis, the former zone correlated by Colbert to the earliest Pleistocene, although he stated in another page, "Archidiskodon planifrons, a primitive elephantine proboscidean first appears in the uppermost Pliocene in India, and almost simultaneously it is found in the uppermost Pliocene of England." It is well known that the proboscidea lived in the Red Crag of Suffolk, England.

The plant remains of the Lower Akasi beds have been carefully studied by $\mathrm{T}$. Miki, ${ }^{8)}$ who found in them 58 species of plants, $31 \%$ of which are those non-existing now in the Japanese Islands. He concluded that the Lower Akasi beds may be contemporaneous with the Mogi plant beds, both being late Pliocene in age. Mention here is needed that nuts of Juglans cinerea and cones of Sequoia japonica Endo are common in these deposits.

The approximate contemporaneity of the Lower Akasi beds of Akasi coast, the plant beds of both Mogi, and Hondo, Amakusa, and the plant beds

3) F. Takai : Notes on Some Cenozoic Mammals from Japan (in Japanese). Jour. Geol. Soc. Japan, Vol. XLVI, No. 552, 1937.

4) J. Makiyama, op. cit., p. 32.

5) W. D. Matthew : Critical Observations upon Siwalik Mammals. Bull. Amer. Mus. Nat. Hist., Vol. LVI, 1929.

6) E. Lewis: A New Siwalik Correlation. Amer. Jour. Sci., Ser. 5, Vol XXXIII, 1937, pp. 191-204.

7) E. H. Colbert: Siwalik Mammals in the American Museum of Natural History. Trans. Amer. Phil. Soc., N. S., Vol. XXVI, 1935, pp. 33, 379.

8) S. Miki: Plant Fossils from the Stegodon Beds and the Elephas beds near Akashi. Jap. Jour. Bot., Vol. VIII, No. 4, 1937. 
of southern Simabara peninsula is, the writer believes, now definitely established on palaeontological evidence. The same can be said about the marine shell-beds directly overlying the plant beds of southern Simabara peninsula and the Maiko shell-beds are equivalent to the Upper Akasi which directly rests on the Lower.

The Kakiu beds of the southern Tama Hills is a representative formation in the Kwantô region, comparable to the Lower Akasi of the Akasi coast, both having in common Sequoia, Juglans cinerea and a probascidea, Parastegodon sugiyamai ( $=P$. ? kwantoensis Tokunaga) Y. Otuka ${ }^{9)}$ first attempted to divide this formation into two, the Minami Tama beds and Tatibana beds, on an intervening line of unconformity, but later he agreed with $\mathrm{K}$. Suzuki in recognizing the divisional line as being stratigraphically too insignificant and took the whole series of sediments as a single continuous one.

The Kakiu beds contain a rich molluscan fauna, consisting of, according to K. Suzuki ${ }^{10)}$ of 135 species of which 30 species, i. e. $22.2 \%$ of the total, are non-living in the Japanese seas. On this study, he concluded thát the fauna shows an intimate affinity with those of the Naganuma shell-beds of Naganuma, Toyoda-mura, Kamakura-gun, and of the Ninomiya shell-beds of Ninomiya, Ninomiya near Oiso, Naka-gun, both in the province of Sagami (Kanagawa prefecture) and not much distant from Kakiu, all being of the late Pliocene.

Y. Otuka, ${ }^{11)}$ who several years ago pursued a thorough researach on the stratigraphy of the district lying between Kanagawa and Huzisawa along the Tôkaidô railway line, established the following stratigraphical succession of the younger Cenozoic deposits well-developed in the area; in descending order,

Simosueyosi series :

Simosueyosi sand and silt beds, with marine shells

Hodogaya gravel bed unconformity

Naganuma series:

Odoriba sand bed, barren of fossils

9) Y. Otuka : Geology of Tama Hills (in Japanese). Jour. Geol. Soc. Japan, Vol. XXXIX, No. 469, 1932.

10) K. Suzuki : Fossil Fauna of Kakiu Beds (I, Molluscs). Jour. Geol. Soc. Japan, Vol. XLI, No. 495, 1934.

11) Y. Otuka : Geologic Structure of the South Kwantô Region, Japan (in Japanese). Bull. Farthq. Research Inst.. Vol. XV, Pt. 4, 1937: 
Kuratubo silt bed, with marine shells unconformity.

Byôbugaura sand and silt alternation beds, marine fossils present

Taya gravel bed, cross-bedded sand and gravels, barren of fossils unconformity.

Naganuma beds, marine sand and silt, rich in marine fossils

The writer once took the base of the Tokyo beds as lying beneath the Naganuma shell-beds, and later beneath the Simosueyosi; now it seems best to extend the Tokyo beds in wide sense, to the base of the Byôbugaura mud (plus Taya gravel), in which the plant beds of Yokohama lie, owing to that the stratigraphical relation of the Byôbugaura mud, Kuratubo silt, Odoriba sand, Hodogaya gravel and Simosueyosi to the underlying rocks can better be explained by overlapping sedimentation of the younger upon the older. The stratigraphical break between the Byôbugaura and the underlying deposits and the time-gap it represents is fairly important though perhaps it is somewhat less so than that between the Naganuma shell-beds and underlying rocks. The former boundary does not seem to have been surpassed by Sequioias and Juglans cinerea, and many other plants now exotic or extinct.

One of the chracteristic molluses of the Naganuma shell-beds is Pecten naganumana Yokoyama, ${ }^{12)}$ which remains occur very rarely, if present, in younger and older deposits. The chronological correlation. of the Ryûkyû limestone and the Yosida-mura shell-beds on one side and Naganuma shell-beds on the other, born in the writer's mind, lies partly on the occurrence of this molluscan fossil in these three deposits

12) H. Yabe and K. Hatai: On the Stratigraphical Significance of Pecten raganumana Yokoyama, and Its Bearing on the Japanese Neogene. Jour. Geol. Soc. Japan, Vol. XLIV, No. 530, 1937. 